\title{
The Trier Ceiling: Power and Status on Display in Late Antiquity
}

\author{
Marice Rose \\ Fairfield University, mrose@fairfield.edu
}

Follow this and additional works at: https://digitalcommons.fairfield.edu/visualandperformingartsfacultypubs

Copyright 2006 Greece and Rome, Published by Cambridge University Press for the Classical Association http://www.classicalassociation.org/Journals/GreeceRome.html

\section{Peer Reviewed}

\section{Repository Citation}

Rose, Marice, "The Trier Ceiling: Power and Status on Display in Late Antiquity" (2006). Visual \&

Performing Arts Faculty Publications. 10.

https://digitalcommons.fairfield.edu/visualandperformingarts-facultypubs/10

\section{Published Citation}

Rose, Marice. "The Trier Ceiling: Power and Status on Display in Late Antiquity," Greece and Rome 53 (2006), 92-109

This item has been accepted for inclusion in DigitalCommons@Fairfield by an authorized administrator of DigitalCommons@Fairfield. It is brought to you by DigitalCommons@Fairfield with permission from the rightsholder(s) and is protected by copyright and/or related rights. You are free to use this item in any way that is permitted by the copyright and related rights legislation that applies to your use. For other uses, you need to obtain permission from the rights-holder(s) directly, unless additional rights are indicated by a Creative Commons license in the record and/or on the work itself. For more information, please contact digitalcommons@fairfield.edu. 


\title{
THE TRIER CEILING: POWER AND STATUS ON DISPLAY IN LATE ANTIQUITY
}

\author{
By MARICE E. ROSE
}

\section{Introduction}

The fourth-century painted ceiling at Trier, Germany was destroyed less than two decades after it was decorated, yet today it is one of the best-known monuments of Late Antique Gaul (figure 1). In excavations begun by Theodor Kempf in 1945, archaeologists collected the ceiling's fragments from the ruins of a Roman house beneath the city's Romanesque cathedral. ${ }^{1}$ Painstaking assembly of the plaster fragments into their original form was completed in 1980. Now displayed in the Trier Episcopal Museum, the ceiling is a rare example of Late Antique domestic painting. ${ }^{2}$ It comprises fifteen trompe l'oeil coffers which are outlined by red and green borders and a yellow guilloche. Each coffer contains an image of a different subject; bust-length female and male single figures alternate with pairs of putti in various active poses.

The ceiling's rarity, its mysterious, unidentified figures, and the possibility proposed by Kempf that it belonged to a palace built by the emperor Constantine have made it the subject of extensive scholarship. Because conservators assembled the ceiling over a thirty-five year span and individual scenes were published as they were completed, the first scholars of the ceiling studied sections in isolation from the whole monument. Attention first focused on the depictions of the woman with the mirror and the woman with the jewel box, because they were the first single figures to be restored and

\footnotetext{
1 The house was first discovered in 1853 and a preliminary excavation in 1906 revealed a few painted fragments, but the area was not thoroughly or scientifically excavated until the 1945-1946 and 1965-1968 seasons. See T. Kempf, 'Die konstantinischen Deckenmalereien aus dem Trierer Dom', Archölogisches Korrespondenzblatt 7 (1977), 147ff.

2 For accounts of the conservation project, see Kempf (n. 1), 150-3 and W. Weber, Constantinische Deckengemäde aus dem rönischen Palast unter dem Trierer Dom (Trier, 1986), 10-25. In addition to the ceiling, the room's painted decoration included walls frescoed with an imitation marble dado below a register of standing figures separated by trompe l'oeil pilasters, but conservators are unable to piece them together. See further J. G. Deckers, 'Die Decke des Trierer Prunksaales', Kolner-Romer Illustrierte 2 (1975), $176 \mathrm{ff}$.
} 


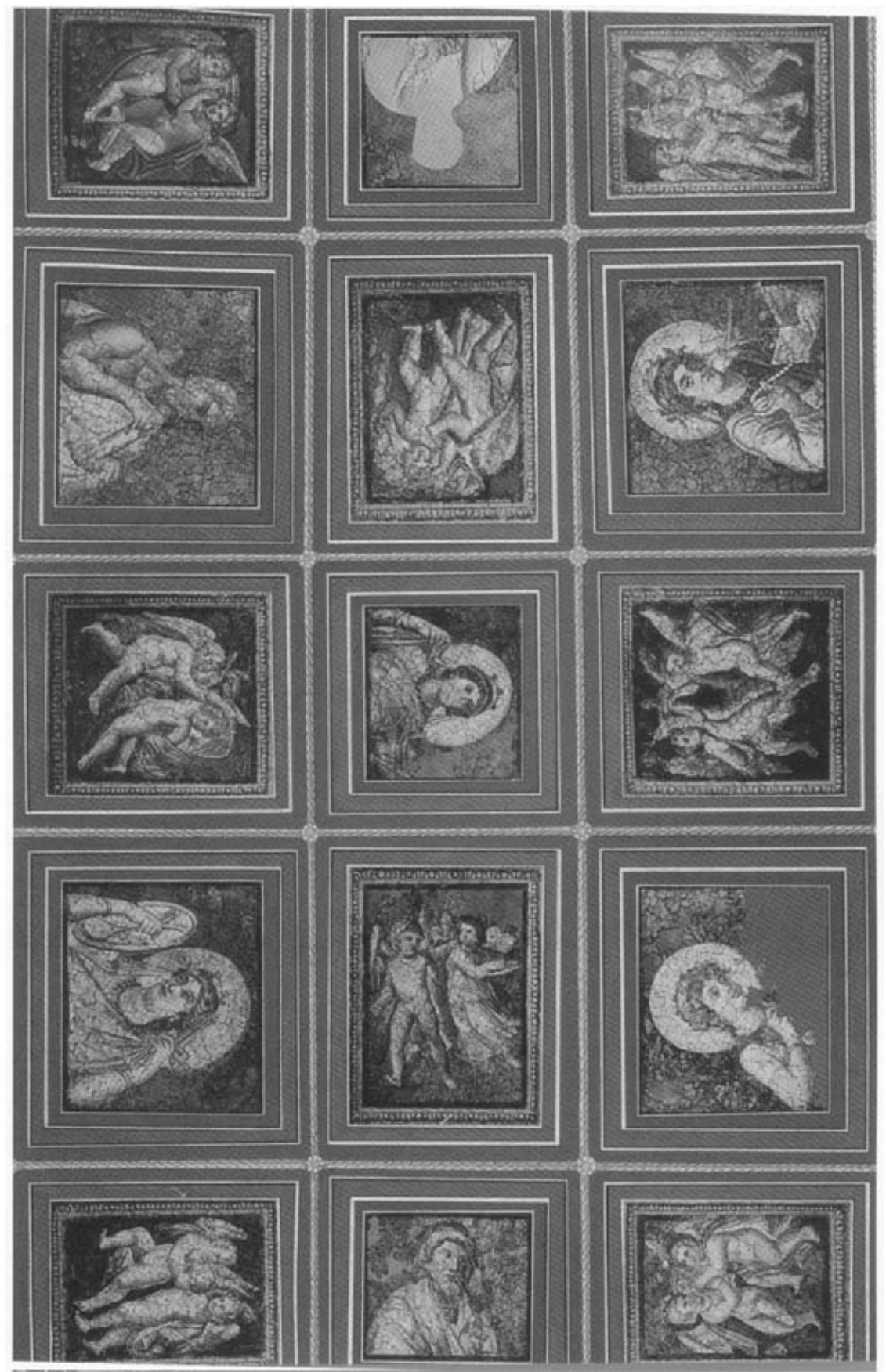

Figure 1. Trier Ceiling. Bischöfliches Dom- un Diözesanmuseum, Trier. 
published. ${ }^{3}$ Many archaeologists and art historians concentrated on identifying the women as portraits of Constantine's family. ${ }^{4}$ Irving Lavin took a different approach and carefully addressed the painting's classicizing style. ${ }^{5}$ Scholars in the 1980 s, with the advantage of the ceiling's completed restoration, have considered the ceiling as a thematic whole. Hugo Brandenburg compared the ceiling's style and content to personifications of wealth and luxury found in Late Antique domestic decoration in Antioch, while Erika Simon fitted the individual images into a complex thematic programme of personifications based on Constantine's panegyric of $310 .{ }^{6}$ In light of current scholarship on domestic decoration and Roman viewership, it is worthwhile to reconsider the Trier Ceiling. Explanations should be sought within the context of Late Antique provincial society. In this paper I argue that the ceiling does not depict portraits of specific people or personifications of specific concepts. Instead, it is a powerful expression of the elevated status and domestic harmony of the ceiling's patron and his family, which also affirms their Roman cultural identity to the ceiling's viewers.

\section{Composition}

On the ceiling's west side is a nimbed, veiled woman in a sleeveless garment, holding a mirror with her right hand and drawing back her transparent veil with her left hand in an anakalypsis gesture. She wears a gold crown featuring protruding blue jewels, earrings, a beaded necklace with pendant gems, and a gold bracelet on each wrist. Two putti separate her from a bearded philosopher-type figure, who wears a plain mantle with no undergarment and holds a scroll with both hands. In the central row, two pairs of putti alternate with three single figures, including another bearded philosopher type on the south side who wears a pallium and a leafy green wreath on his head. He makes a gesture of speech with his left hand. ${ }^{7}$ On the north side of this row is a poorly preserved image of a man who may also be a philosopher. In

3 T. Kempf, 'Konstantinische Deckenmalereien aus dem Trierer Dom', Trier. Ztschr. 19 (1950), 45ff.

4 See below pp. 99-101.

5 I. Lavin, 'The Ceiling Frescoes in Trier and Illusionism in Constantinian Painting', DOP 21 (1967), 99ff.

6 H. Brandenburg, 'Zur Deutung der Deckenbilder aus der Trierer Domgrabung', Boreas 8 (1985), 143ff.; E. Simon, Die Konstantinischen Deckengemäde in Trier (Mainz, 1986).

7 Most of the area of the figure's hand does not survive, so the restoration may not be fully accurate. 
the centre of the ceiling is a nimbed, veiled woman with a string of pearls in her hair, a crown with three large blue gems, and a necklace of round blue stones. She holds a silver kantharos in her right hand and draws back her veil with her left hand. Her garment wraps tightly around her left shoulder. In the easternmost row, the single figures include a nimbed, veiled woman in a long-sleeved garment with a gold palla, a gold crown with gems on top of her head, a leafy garland and pearls in her hair, and a necklace of large blue gems. She draws a pearl necklace from a square box with raised lid. Also in this row survives only three-quarters of a nimbed figure of unknown gender with a floral garland on the head, and a sleeveless garment revealing the right arm with bracelets on wrist and upper arm. ${ }^{8}$ The figures are arranged so they face the edges of the room, except for the woman in the centre, who is oriented to the West. Evidence left by the ceiling's technique of manufacture confirms that the reconstructed images on the ceiling are in their original order. ${ }^{9}$

\section{Archaeological evidence}

There is no epigraphic evidence of the Trier Ceiling's patron or date, and the plan of the room to which the ceiling belonged is also elusive. Excavation shows that the irregularly-shaped room, approximately $7 \mathrm{~m}$. by $10 \mathrm{~m}$., was probably built sometime between 315 and the early 330 s on the foundation of an existing peristyle house. ${ }^{10}$ There was a door in the room's northwest corner, and a door in the south wall of the room that led to an approximately $3 \mathrm{~m}$. by $5 \mathrm{~m}$. anteroom. ${ }^{11}$ The complete plan and dimensions of the building to which the room belonged are impossible to determine, however, because of later

${ }^{8}$ In the figure's upraised right hand is an object that in the restoration of 1948 was interpreted as a plectron, and so in the resulting reconstruction conservators painted a lyre in the figure's left hand. The accuracy of the restoration is doubtful and was removed, but can be seen in older reproductions of the ceiling.

9 The ceiling plaster was applied to a mat of woven reeds that had been nailed onto the beams of the ceiling. The lattice pattern of the reeds, preserved on the backs of the painted fragments, was used to assemble the pieces. See Weber (n. 2), 16.

${ }_{10} \operatorname{Kempf}(\mathrm{n} .1), 153$. A coin minted in 315, discovered in the mortar of the room's pavement mosaic, indicates an approximate date for the ceiling's decoration, if the pavement and ceiling were contemporaneous. A coin found under the pavement of the southeast basilica dates it to after 330; see H. Heinen, Frihchristliche Trier (Trier, 1996), 111. Kempf (n. 1), 158, suggests that the room was decorated in 321 and destroyed in 326. Simon (n. 6), 52, dated the painting more closely to 315 because of the perceived pagan nature of the imagery, while Brandenburg (n. 6, 148), arguing that the numismatic evidence is problematic, dates the ceiling on stylistic grounds to the third quarter of the fourth century.

11 Weber (n. 2), 8 f. 
construction on the site. A series of ecclesiastical structures was built on the house's foundation and joined together, resulting in a double basilica-plan church. ${ }^{12}$ Because of the construction of this basilica's sanctuary, the painted room was damaged and the ceiling fell. The room to its north was destroyed by building activity within the fourthcentury basilica, and the room to its east was destroyed by the addition of an early medieval crypt to the basilica. ${ }^{13}$ In the eleventh century, the sinking of a pier during the cathedral's construction further damaged the site. Although the plan of the house cannot be further reconstructed, the large size of room and the quality and subject of its frescoed decoration suggests that the home was built by an élite patron. ${ }^{14}$ Excavation revealed an added luxury, heating ducts. ${ }^{15}$

\section{Context}

In the past twenty years, scholars have begun to consider Roman domestic architecture and its decoration within the contexts of patron, function, and audience. The notion that the Roman patron expressed his family's identity and status through the architecture and decoration of their home is accepted. Andrew Wallace-Hadrill and John Clarke have examined houses, primarily in Pompeii, with regard to the social rituals that occurred within the rooms, and the corresponding differences in messages intended for the patron and for visitors. ${ }^{16}$ Bettina Bergmann and Jas Elsner have explored the influence of Roman rhetoric on the domestic viewers' experiences and understandings of images. ${ }^{17}$ Recently, Shelley Hales has considered the Roman domus as a visual construction of the Romanitas of its patron's family, offering examples in Pompeii and in the provinces. ${ }^{18}$

12 For the later construction activity, see Heinen, (n. 10), $109 \mathrm{ff}$.

13 Heinen (n. 10), 109ff.

14 The room is $6.8-7 \times 9.75-9.95 \mathrm{~m}$. By élite, I mean members of the uppermost echelon of society who shared cultural values. See J. Clarke, Art and the Ordinary Roman Viewer (Berkeley, 2002), $4 \mathrm{f}$., for discussion of the definition of élite.

15 Weber (n. 2), 8.

16 A. Wallace-Hadrill, Houses and Society in Pompeii and Herculaneum (Princeton, 1994); J. Clarke, The Houses of Roman Italy, 100 B.C.-A.D. 250: Ritual, Space, and Decoration (Berkeley, 1991), id. (n. 14).

17 B. Bergmann, 'The Roman House as Memory Theater: The House of the Tragic Poet in Pompeii', Art Bulletin 76 (1994), 225ff. J. Elsner, Art and the Roman Viewer: The Transformation of Art from the Pagan World to Christianity (Cambridge, 1995); Z. Newby expands the approach from painting to the Spada reliefs in 'Reading Programs in Greco-Roman Art: Reflections on the Spada Reliefs', in D. Frederick (ed.), The Roman Gaze: Vision, Power, and the Body, (Baltimore, 2002), $110 \mathrm{ff}$.

18 S. Hales, The Roman House and Social Identity (Cambridge, 2003). 
As Hales emphasizes, in Roman domestic architecture all rooms were potentially public, with few 'private' spaces for the inhabitants; therefore, the whole house and its decoration projected the patron's desired image for himself and his family. ${ }^{19}$

This is especially true in Late Antiquity, because of the increased emphasis given to ceremony, which led to more guests and therefore more viewers for the patron's message. ${ }^{20}$ For example, reception rooms were an important aspect of late Roman domestic architecture, because political functions that had once taken place in public now occurred in élite homes. ${ }^{21}$ Within the social realm, banquets also became more elaborate with more guests, and therefore triclinia became larger. ${ }^{22}$ The significance of impressing guests is seen in the writings of Apollinaris Sidonius, who describes his villa in Gaul c. 460 $\mathrm{AD}$, focusing on his bathing and dining areas as the places of entertainment, detailing the impression they make. ${ }^{23}$ Approaching the Trier ceiling through a lens of viewer reception is particularly valuable in a provincial imperial city such as Trier, where not only the self-perception of the local élite was important, but also the message expressed to their clients and guests, just as it was for Sidonius. As Webster writes, 'issues of identity and power are represented, contested, and resolved' through art, especially in 'intercultural contexts'. ${ }^{24}$ Patrons would want to communicate their power through their wealth and through their Romanitas to a varied audience: men and women, Romans and locals, personal guests and clients.

\section{Patronage and meaning}

Many have assumed that the patron of the ceiling was the most powerful man in the empire. Since the ceiling was published, Kempf and subsequent scholars have linked it to Constantine and his family. ${ }^{25}$ Constantine moved to Trier after he was proclaimed

19 Hales (n. 18), $132 \mathrm{ff}$.

20 S. MacCormack, Art and Ceremony in Late Antiquity (Berkeley and London, 1981); J. Elsner, Imperial Rome and Christian Triumph (Oxford and New York, 1998).

21 According to S. Ellis, 'The End of the Roman House', AfA 92 (1988), 569, audience chambers can be identified in houses in Apollonia, Ephesus, and Aphrodisias.

${ }^{22}$ K. Dunbabin, 'Convivial Spaces: Dining and Entertainment in the Roman Villa,' $\mathcal{F} A 9$ (1996), $77 \mathrm{ff}$.

23 Sidonius, Ep. 2.2.

24 J. Webster, 'Art as Resistance and Negotiation', in S. Scott and J. Webster (eds.), Roman Imperialism and Provincial Art (Cambridge, 2003), 24.

25 A. Alföldi, 'Zur Erklärung der konstantinischen Deckengemälde in Trier', Historia 4 
emperor in 306. Trier had become a capital of the western empire under Diocletian, and Constantinus Chlorus, Constantine's father, took up residence in 293. Constantinus Chlorus built city walls, baths, and the palace complex to which the surviving basilica belonged. Before it was made capital, Trier already was an important provincial Roman city. Founded in honour of Caesar Augustus in 15/16 BC in the land of the Celtic Treveri tribe, it was prosperous, with a forum, a theatre, and elaborate homes, such as the one to which the ceiling belonged. ${ }^{26}$ Kempf suggested that Constantine acquired the preexisting house and constructed the palace with the painted room in order to expand the residence into a palace for his son Crispus. ${ }^{27}$ Crispus moved to Trier in 316 and became Caesar in 317. The domestic complex was destroyed and became the foundation for a series of churches at some point after Constantine had Crispus killed. ${ }^{28}$ If the house did belong to Crispus, it is possible that it was destroyed as a damnatio memoriae and the churches were built over it for atonement. ${ }^{29}$ No inscriptions or contemporaneous textual evidence positively link the domestic complex to Crispus or to other members of Constantine's family, but later medieval legends purport that Constantine's mother, Empress Helena, donated her home for the foundation of an episcopal church in Trier. ${ }^{30}$ The privileged nature of the room's location, near the basilica and on a high elevation, has reinforced the argument that it may have been in an imperial district. $^{31}$

One must be wary, however, of assigning monuments to imperial patrons with no definitive evidence. Houses on high ground were important not just for emperors, but for aristocrats who wanted to enhance their prestige by making their houses prominently visible. ${ }^{32}$

(1955), 131ff.; M. Alföldi, 'Helena nobilissima femina. Zur Deutung der Trierer Deckengemälde', Fahrbuch fur Numismatik und Geldgeschicte 10 (1960), 79ff.; W. Schumacher, 'Cubile Sanctae Helenae', RönQSchr 58 (1963), $211 \mathrm{ff.}$

26 See E. M. Wightman, Trier and the Treveri (London, 1970), 71-123; and Heinen, Trier und das Trevererland in römischer Zeit (Trier, 1985).

27 Kempf, 'Der konstantinische Prunksaal unter der frühchristlichen Basilica', in W. Reusch (ed.), Frihchristliche Zeugnisse im Einzugsgebiet von Rhein und Mosel (Trier, 1965), 240.

${ }_{28}$ For a review of the contemporaneous and later medieval sources regarding the death of Crispus, see H. A. Polsander, 'Crispus: Brilliant Career and Tragic End', Historia 33 (1984), 79ff. According to medieval legend, Constantine had Crispus and his wife Fausta executed after they committed adultery together. Although modern scholars do not believe that the infidelity occurred, Fausta and Crispus must have been thought guilty of a great offence, because Constantine had previously shown them no sign of disfavour.

$29 \operatorname{Kempf}($ n. 1), 158.

30 For discussion of legends and traditions relating Helena to Trier, see Heinen (n. 10), $77 \mathrm{ff}$.

31 Heinen (n. 10), 115.

32 Hales (n. 18), $44 \mathrm{f}$. 
Scholars thought another great domestic structure, Piazza Armerina in Sicily, was an imperial residence but now associate it with a member of the provincial aristocracy. ${ }^{33}$ Similarly, after World War I, several prominent European art historians focused on defining Early Christian sacred iconography in imperial terms. ${ }^{34}$ The association of monuments with imperial patrons despite a lack of secure evidence may reflect the 'nostalgia for lost empire' that Thomas Mathews sees in early twentieth-century studies of Early Christian iconography. Although Mathews does not include the secular Trier Ceiling in his study of Christian imagery, his theory has particular resonance if applied to the scholarship of the ceiling. In World War II, the Trier cathedral was bombed, and the first major excavations under the cathedral took place after German surrender. The identification of the domestic building with Constantine and his family may show nostalgia for a more admirable time in German history, when Germany was home to the first Christian emperor and Trier was a capital of a vast empire. ${ }^{35}$

As proof that the house was an imperial residence, art historians and archaeologists identified the ceiling's richly dressed, nimbed women as members of Constantine's family. While the ceiling's reconstruction progressed in the 1950s and 1960s, scholars named the four nimbed portraits as Empress Helena, Constantine's wife Empress Fausta, Crispus' wife Helena II, and Constantine's sister Constantia. No consensus could be reached, however, as to which portrait depicts which woman. Kempf originally identified the woman with the jewel box as Constantine's wife, Empress Fausta; he named the 3/4-preserved figure, on the basis of her laurel wreath that he surmised only a princess would wear, as Crispus' wife Helena; the woman in the central panel he perceived as appearing older and therefore representing Empress Helena. ${ }^{36}$

After more fragments were discovered and integrated into the ceiling, Kempf modified his original identifications. In his estimation, the woman in the centre was still Helena, but he changed the identity of the woman with the jewel box to Constantine's sister Constantia

33 A. Carandini, A. Ricci, and M. de Vos, Filosofiana: The Villa of Piazza Armerina (Palermo, 1982), 28.

${ }_{34}$ T. Mathews, The Clash of Gods (Princeton, 1993; rev. ed. 1996), 19. Mathews' theories are problematic in their absolutism in terms of Early Christian iconography. See P. Brown review, Art Bulletin 77 (1995), 499ff.

35 See also R. Leader, 'The David Plates Revisited', Art Bulletin 82 (2000), 407ff. for a new interpretation of monuments that have been overly interpreted as having imperial iconography.

${ }^{36} \operatorname{Kempf}($ n. 27), 244f. 
after the reconstruction of the hitherto unknown panel depicting the woman with the mirror, whom he suggested was Fausta. He proposed that the ceiling was painted for Helena's seventieth birthday. ${ }^{37}$ Andreas Alföldi interpreted the woman in the central panel as Helena, the woman with the jewellery box as Fausta, and the 3/4-preserved figure as Constantia. ${ }^{38}$ Maria Alföldi identified the woman with the jewel box as Helena, mother of Constantine; the 3/4-preserved woman as Helena, bride of Crispus; and the woman in the centre as Fausta. ${ }^{39}$ Schumacher saw the central figure as Helena the younger, and the woman with the jewel box as Fausta, within a broad theme of matrimony, assigning the painting of the ceiling to the occasion of Crispus' marriage in $321 .{ }^{40}$

Scholars' disagreement shows that it is virtually impossible to identify positively the figures, and despite their jewellery and nimbuses it is not certain the figures are empresses at all. Lavin and Brandenburg point out that it is unusual for empresses to be shown in such informal poses as looking into mirrors and putting on jewellery, and juxtaposed not with emperors but with philosophers and putti. ${ }^{41}$ It is doubtful the figures would have been recognized as depicting specific imperial women. ${ }^{42}$ The sculpted portraits that have been tentatively identified as portraits of Helena, Fausta, or Helena the younger, and inscribed images on coins of Helena and Fausta, do not bear strong resemblances to the ceiling's images. ${ }^{43}$ The women's faces on the ceiling are not individualized, but, as noted by Archer St. Clair, are a type revived often from Hellenistic models in the fourth century. ${ }^{44}$ The women on the ceiling wear crowns, but not jewelled

${ }^{37}$ Kempf, 'Das Haus der Heiligen Helena', Neues Trierisches Fahrbuch (1978), $1 \mathrm{ff}$.

38 Alföldi (n. 25) isolated the imperial imagery in the ceiling, such as the purple mantles worn by the putti, the silver globe, the cornucopia, and the rich ornaments worn by the women.

39 Alföldi (n. 25), 79ff.

40 Schumacher (n. 25), $211 \mathrm{ff}$.

${ }^{41}$ Lavin (n. 5), 101, Brandenburg (n. 6), 161.

42 While emphasis has been given to identification of the women as imperial individuals, in Late Antiquity one can rarely identify empress portraits with precision, because the aim of imperial portraiture in this period was more to depict status or virtue than physical likeness. A. St. Clair, 'Imperial Virtue: Questions of Form and Function in the Case of Four Late Antique Statuettes', DOP 50 (1996), 152; L. James Empresses and Power in Early Byzantium (London, 2001), 36f. Sometimes empresses were given the physical characteristics of their husbands; R. R. R. Smith, 'Roman Portraits', fRS 75 (1985), $214 \mathrm{f}$.

${ }^{43}$ For portraits of Constantinian women, see I. Kalavrezou (ed.), Byzantine Women and their World (New Haven, 2003); R. Calza, Iconografia romana imperiale da Carausio a Giuliano (287-363 d.c.), Quaderni e guide di archeologia 3 (Rome, 1972), R. Delbrueck, Späantike Kaiser porträs (Berlin, 1933); C. Vermeule and M. Comstock, Greek and Roman Portraits (Boston, 1972).

${ }^{44}$ St. Clair (n. 42), 151. Hairstyles are often a useful indicator in Roman portrait identification, but on the ceiling they are difficult to recognize because of the women's veils. 
diadems, which Constantine introduced, and Helena and Fausta are depicted as wearing diadems on coins. ${ }^{45}$ As evidenced by the ornately jewelled women in the Dominus Iulius mosaic and the bath mosaics at Sidi Ghrib and Piazza Armerina, elaborate jewellery was common in the period and does not brand the women as empresses. ${ }^{46}$ The rich ornaments worn by the women, as well as the silver and gold objects they hold, exemplify the characteristically Late Antique desire to communicate status and wealth through conspicuously expensive jewellery and clothing. In Late Antiquity personal adornments were more opulent than in previous centuries. ${ }^{47}$ Images of precious portable objects such as jewellery boxes, vessels like the kantharos, and mirrors, would indicate material prosperity and would reflect the actual possessions of the patron. ${ }^{48}$ Neither are nimbuses necessarily indicators of imperial status. In the fourth century there was no standard formula for the use of nimbuses; they are worn by a broad range of figures including gods, deceased mortals, and personifications. ${ }^{49}$

As some art historians have seen individual historical figures in the women, others have seen personifications of specific concepts. Simon identifies the woman with the mirror as Sapientia (wisdom), the woman with the jewel box as Pulchritudo (beauty), and the woman with the kantharos as a portrait of Fausta with characteristics of both Iuventas (youth) and Salus (health), within the context of Constantine's Panegyric of $310 .{ }^{50}$ A lack of comparative visual evidence for these personifications weakens her argument. Brandenburg interprets the ceiling images as generally evoking personifications of the pleasures of a cultivated life, specifically Chresis (good use of acquired wealth) and Tryphe (luxury), as appear on contemporaneous, inscribed pavement mosaics in Antioch. ${ }^{51}$ Although personifications in Late Antiquity often appear similar to the ceiling's figures, as richly dressed bust-length figures with nimbuses and leafy wreaths, I believe that the ceiling's images do not depict particular personifications. Without inscriptions or standard attributes, they are not recognizable, and their gestures are not typical for personifications. It is virtually impossible, however, for today's viewer to identify positively the figures as

45 St. Clair (n. 42), 151; Byzantine Women, cat. 16 and 17.

46 L. Ennabli, 'Les thermes des thiases marines de Sidi Ghrib', MonPiot 68 (1986), 43; Carandini, Ricci, and de Vos (n. 33), 326.

47 J. Bruhn, Coins and Costume in Late Antiquity (Washington D.C., 1993), 33; H. Maguire, 'The Good Life', in Bowersock, Brown, and Grabar (eds.), Late Antiquity (London, 1999), 242.

48 J. Lerner, 'Horizontal Handled Mirrors,' MMAf 31 (1996), $11 \mathrm{ff}$.

49 M. Collinet-Guerin, Histoire du nimbe (Paris, 1961), 213f., 338.

50 Simon (n. 6), $40 \mathrm{ff}$.

51 Brandenburg (n. 6), $184 \mathrm{ff}$. 
such, and it would have been equally difficult for the Late Antique viewer without inscriptions or typical attributes and gestures. In a discussion of the ceiling's classicizing style, Lavin writes, '[the women] seem, rather, to be deliberately suggestive, intended to evoke an ideal, indeed classical, mood of physical and spiritual well-being, from which turmoil and anxiety have been banished. ${ }^{52}$ Henry Maguire notes that in Late Antique domestic contexts, richly dressed personifications often were not inscribed and in fact were not meant to be distinct concepts, but they served as 'unspecific beneficent presences', guaranteeing abundance with an almost magical power. Such an abundant magical effect is most likely the intent of the figures on the ceiling.

I propose that the women's costumes, attributes, and personification-like nimbuses and wreaths construct a beneficent theme of not only physical well-being through wealth but also familial well-being in terms of domestic harmony. The anakalypsis gesture of pulling back the veil from the face, as performed by the woman with the kantharos and the woman with the mirror, is not seen in personifications. Anakalypteria, in classical Greece, was the moment in the wedding when the bride was unveiled and her face was revealed. ${ }^{53}$ In Rome, the anakalypsis gesture defined a woman's status as a proper matron. ${ }^{54}$ The gesture is common in images of women on classical Greek wedding vases and grave stelai and on Roman sarcophagi. It is appropriate that the ceiling's decorative program would not only promote material prosperity, but also domestic prosperity, owing to the importance in Roman culture of constructing the family's identity through visual means.

On the ceiling, the combination of the anakalypsis with references to Venus further strengthens the evocations of domestic happiness. A sophisticated viewer certainly would have recognized that the additional gestures of the ceiling's nimbed women looking into a mirror and a jewel box are ones often used for the goddess Venus. An example of a mortal woman imitating Venus is seen on the Proiecta Casket from the Esquiline Treasure. Directly under the image of Venus and her entourage is an image of a woman, probably Proiecta (named by inscription on the casket's lid), who holds a pyxis and is offered a mirror by a servant. The echoing composition associates the

52 Lavin (n. 5), 102.

53 J. Oakley and R. Sinos, The Wedding in Ancient Athens (Madison, Wisconsin, 1993), 25f.; Oakley, 'The Anakalypteria', $A A$ (1982), $113 \mathrm{ff}$.

54 S. Treggiari, Roman Marriage (Oxford, 1991), 163. 
mortal woman with the goddess. ${ }^{55}$ Although the Trier Ceiling's women are not portraits of living women, the viewer would have seen the women as displaying general characteristics and attributes of the goddess. The gold crowns on the heads of the women may evoke the Homeric description of Aphrodite as golden-crowned; she is often depicted on pavement mosaics with a crown. ${ }^{56}$ References to Venus do not mean that the patron was pagan. The great number of Late Antique depictions of the toilet of Venus are not related to greater pagan religious devotion to her, because votive dedications and temples dedicated to her did not increase at this time. ${ }^{57}$ Even as Christianity became dominant, Venus retained her association with beauty, love, and fertility. Katherine Dunbabin suggests that images of Venus had a magical, talismanic effect of improving health and fertility for both Christians and non-Christians. ${ }^{58}$ Dunbabin's suggestion is supported by fourth century epithalamia used by both Christians and pagans that refer to Venus's toilet. ${ }^{59}$

The ceiling's putti in the context of the images of the women also refer the viewer to the goddess Venus, and to other associations as well. Scenes of putti and Venus with mirror and jewel box were familiar to the Late Antique Roman viewer. On the Proiecta Casket, the crowned Venus looks into a mirror while a putto offers a jewel box (figure 2). ${ }^{60} \mathrm{~A}$ third-century mosaic from Bulla Regia depicts one putto holding a jewel box and a second one holding a mirror for Venus. ${ }^{61}$ The ceiling's putti also magically evoke material abundance and domesticity, echoing the female figures. They are richly dressed, all wearing gold necklaces and armbands, and purple mantles, and holding objects that include a gold vessel, gold lamps, a cornucopia, and a silver sphere. ${ }^{62}$ Resembling but not following any established

55 J. Elsner, 'Visualising Women in Late Antique Rome: the Projecta Casket', in C. Entwistle (ed.), Through a Glass Brightly; Studies in Byzantine and Medieval Art and Archaeology, presented to David Buckton, (London, 2003), $31 \mathrm{ff}$.

56 Homeric Hymn 6.1. See M. Levine, 'The Gendered Grammar of Ancient Mediterranean Hair', in Eilberg-Schwartz and Doniger (eds.), Off With Her Head (Berkeley, 1995), 76ff., for a study on veils and crowns. Although Rumpf identified the woman with the mirror as Venus, the fact that all of the women are surrounded by putti, wear gold crowns, and two of them hold Venus-like attributes, suggest that none of the women is meant to be recognized as a representation of the goddess.

57 K. Dunbabin, Mosaics of Roman North Africa (Oxford, 1978), 157.

58 Dunbabin (n. 57), 157.

59 L. Stirling, 'Epithalamia and Imagery of Venus in Late Antiquity', A尹A 102 (1988), 410.

60 Elsner (n. 55), $22 \mathrm{ff}$.

61 From the Maison d'Amphitrite, Dunbabin (n. 57), 155. See also mosaics from Djemila, Setif, and Utica, $155 f$.

62 Putti, prevalent in Roman art in all media, including painted ceilings, were undoubtedly common in Trier. A fragment of a different ceiling, painted with a blond, naked, winged putto 


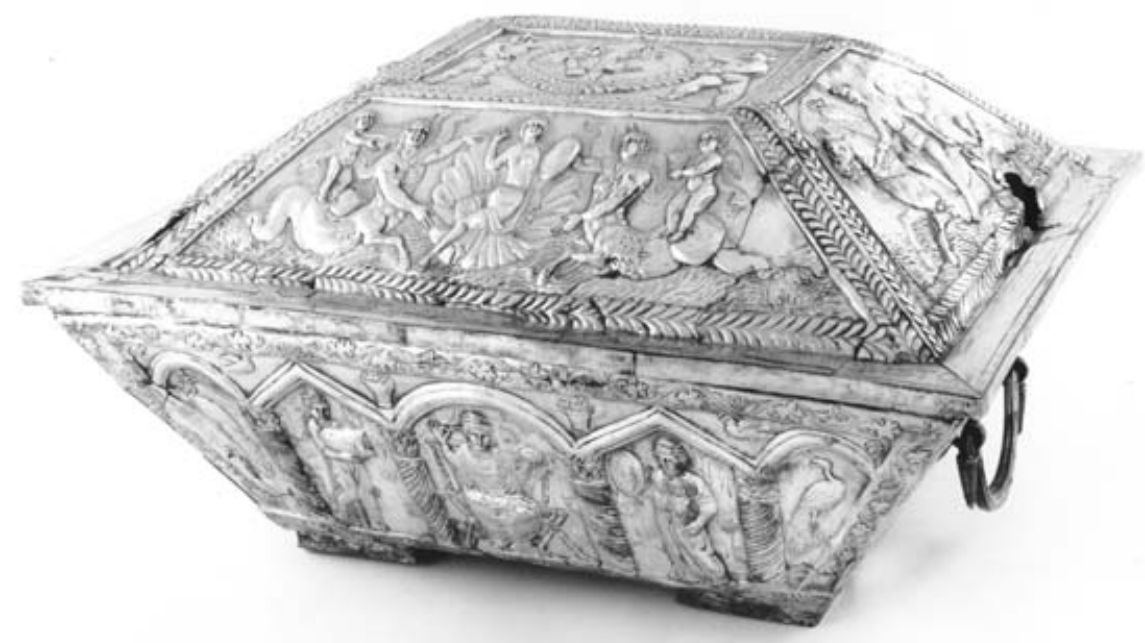

Figure 2. Proiecta Casket. Copyright (C) The Trustees of the British Museum, London.

iconography of specific personifications, the dancing figures call to mind seasonal personifications found on domestic pavements dating to the late third century, but seasons appear singly and with standard attributes, such as a plate of flowers for spring. ${ }^{63}$ Instead, the dancing putti are general symbols of abundance and domestic happiness. ${ }^{64}$ Sustaining the theme of domestic harmony is the coffer that contains a putto and a winged female figure in a white robe. Weber has recognized the pair as Cupid and Psyche in the scene from Apuleius' Metamorphosis, after Venus sent Psyche for Proserpina's beauty ointment. ${ }^{65}$ Psyche carries a flat gold vessel that contained the beauty

on a dark brown background was excavated from a c. 320 building under the church of St. Maximin in the city. Trier, Kaiserresidenz und Bischofssitz, exh. cat. (Mainz, 1984), 236-7. Jewellery is not uncommon in fourth-century images of putti. For example, in Piazza Armerina, putti wear necklaces and multiple bracelets on their arms and ankles, and in Sousse, they wear necklaces with pendants and bracelets. See Dunbabin (n. 57), 105-6, fig. 94; Carandini, Ricci, and DeVos (n. 33), 254-7, figs. 149ff.; 309.

${ }^{63}$ From the House of the Drinking Contest. See D. Levi, Antioch Mosaic Pavements (Princeton, 1977), 161, pl. 32.2b. For discussion of Season images and other references to time in the Roman house, see C. Kondoleon, in Kondoleon (ed.), 'Timing Spectacles: Roman Domestic Art and Performance', Art of Ancient Spectacle (New Haven, 2000), $321 \mathrm{ff}$.

64 One exception is Winter in the House of the Drinking Contest, who is depicted with what has been interpreted as a thymeterion, like the putto on the east side of the ceiling, in the centre. Levi (n. 63), 162.

65 Apul., Met. 6.21. Weber (n. 2), 22. 
ointment and Cupid holds the golden arrow with which he woke Psyche from her death-like sleep after she tested the ointment. It is the only known surviving illustration of this particular passage, underscoring the wide range of sources of inspiration for the Trier ceiling's designer. ${ }^{66}$

The depiction of the scene serves as another reference to Venus, but more importantly the illustration of Apuleius is typical of the ways in which élite patrons invoked Roman culture to signal their status and Romanitas. Through its Hellenizing, naturalistic style and its subject matter, the ceiling continues the retrospective interests of the Second Sophistic, a conscious promotion of Rome's classical cultural heritage that began in the mid-second century AD. ${ }^{67}$ It was within the Second Sophistic that luxuria was no longer viewed negatively, and conscious displays of status within the house were more accepted. ${ }^{68} \mathrm{In}$ Late Antiquity, references to both the Greek and Roman pasts were common in aristocratic domestic decoration, especially in displays of statues from Greece and Rome. ${ }^{69}$ Recalling aspects of the second century $\mathrm{AD}$ was especially popular, and this is reflected in the Apuleius illustration and the ceiling's putti, who reflect dancing putti found in second-century imperial propaganda such as triumphal arches. ${ }^{70}$ Painted in the fourth century, the ceiling's classicism was a means of forging a link with the more glorious past. ${ }^{71}$ Such retrospection promotes the cultural link with the empire, or Romanitas, of the house's inhabitants, which was important socially and politically. ${ }^{72}$

It was common for walls, floors, and even apparently ceilings of Late Antique élite homes to be decorated with scenes from Greek and Roman literature and mythology such as the Cupid and Psyche scene. Such decoration revealed the familial happiness, cultural heritage, and education of its patron, and also facilitated learned conversation

66 C. C. Schlam, Cupid and Psyche: Apuleius and the Monuments (University Park, Pennsylvania, 1976), 26ff. There is a mosaic in Antioch that depicts Psyche asleep and Cupid about to wake her. Simon (n. 6), 20.

67 For the Second Sophistic as relates to Roman art, see Elsner (n. 20), 169ff.; S. Swain, Hellenism and Empire: Language, Classicism and Power in the Greek World A.D. 50-250 (Oxford, 1996); Bowersock, Hellenism in Late Antiquity (Cambridge, 1990).

68 Newby (n. 17), $113 \mathrm{f}$.

69 Elsner (n. 20), 187. Liz James, "Pray Not to Fall into Temptation and be on Your Guard": Pagan Statues in Christian Constantinople', Gesta 35 (1996), 12ff.; S. Guberti Bassett, " Excellent Offerings": The Lausos Collection in Constantinople', Art Bulletin 82 (2000), $6 \mathrm{ff}$.

70 Kiilerich, Fourth Century Classicism in the Plastic Arts (Odense, 1993), 225, 234; G. Hanfmann, The Season Sarcophagus in Dumbarton Oaks (Cambridge, Mass., 1951), $172 \mathrm{ff}$.

71 Elsner (n. 20), 186ff.

72 See further Hales (n. 18), 13ff., for her discussion of Romanitas as being based not on ethnicity but traditional mores. 
within the room. Paideia, the educational system whereby poets and philosophers taught the sons of the élite, was another status symbol that distinguished the Roman élite from the lower classes. ${ }^{73}$ As Brown discusses, geographically scattered segments of the ruling class had a common education through paideia, which 'provided a shared imaginative landscape for those whose careers took them, increasingly, far from their native cities'. ${ }^{74}$ The subject matter would serve as a topic of conversation, and therefore also gave certain audiences power, because only an educated viewer could identify and discuss the scene. ${ }^{75}$ The concept of one's education being revealed through an understanding of domestic decoration was understood in antiquity. Lucian of Samasota, in a second-century AD text describing a room, writes: 'The exactness of [the wall paintings'] technique and the combination of antiquarian interest and instructiveness in their subjects are truly seductive and call for a cultivated spectator. ${ }^{76}$

The ceiling's depiction of three men in philosophers' garb reinforces this evocation of the patron's education. Sculpted philosopher portraits were a traditional element of élite Roman villas in the first and second centuries, and images of philosophers continued to be popular in Late Antiquity. ${ }^{77}$ Although the philosopher types are the most poorly preserved of the ceiling's figures, surviving segments reveal that the men wear the pallium, the distinctive garment of intellectuals in the Roman and Late Antique eras. ${ }^{78}$ Their undyed, unembellished garments and grey hair contrast with the youth, ornate costume, and gold and silver accessories of the women, and their seriousness is antithetical to the mood of the cavorting putti next to them. These oppositions highlight the philosophers' lack of concern for the mainstream values of society. Philosophers played important roles in Late

73 H. I. Marrou, A History of Education in Antiquity (New York, 1956); R. Kaster, Guardians of Language: The Grammarian and Society in Late Antiquity (Berkeley, 1988); Brown, Power and Persuasion in Late Antiquity (1992), 36ff.

74 Brown (n. 73), 41.

75 For consideration of paideia in domestic contexts, see Newby (n. 17), 110-48; Leader (n. 35); S. Scott, 'The Power of Images in the Late Roman House', in Ray Laurence and Andrew Wallace-Hadrill (eds.), Domestic Space in the Roman World: Pompeii and Beyond (Portsmouth, RI, 1997), 58.

76 Lucian, De domo 21.

77 S. Dillon, 'Subject Selection and Viewer Reception of Greek Portraits from Herculaneum and Tivoli', FRA 13 (2000), $21 \mathrm{ff}$.; T. Lorenz, Galerien von griechischen Philosopher- und Dichterbildnisse bei den Rönern (Mainz, 1965).

78 P. Zanker, The Mask of Socrates (Berkeley and Oxford, 1995), 281-2. The difference in dress between the philosopher who wears an undergarment and the one who does not must be conscious on the part of the artist, referring to different philosophical schools. Figures without undergarments would be understood as being more ascetic, as on a c. A.D. 280 sarcophagus. See $277 \mathrm{ff}$., fig. 150 . 
Antiquity, as teachers and advisers to the ruling class, but they remained separate from the established social hierarchy. They were admired for their wisdom and for the strength of character that allowed them to avoid normal societal rituals. ${ }^{79}$ The inclusion of philosophers and poets in Late Antique domestic decoration is mirrored elsewhere in Gaul, in sculpture and in mosaic, with other examples in Trier. ${ }^{80}$ The images refer to the culture to which provincial aristocrats wanted to show they belonged.

The men have been named as specific philosophers, similar to the women's being identified as various empresses and personifications, but scholars disagree as to which philosophers are depicted. Kempf named the man with the scroll as Lactantius, a philosopher in Constantine's court. ${ }^{81}$ Simon identified the man with the wreath as Apuleius, the man with the scroll as Heraclitus, and the poorlypreserved man with the scroll as Virgil. ${ }^{82}$ Weber identified the man with the wreath as Apuleius. ${ }^{83}$ Brandenburg, however, recognized the men as general symbols of learning. ${ }^{84}$ It would have been equally difficult for a Late Antique viewer to identify the figures as individual philosophers, for already in Late Antiquity portraits of ancient Greeks and Romans lost some of their traditional characteristics; the other philosopher or poet images in Gaul are inscribed, but few exactly follow their earlier individualized portrait types. ${ }^{85}$ The lack of specificity in the images may have been intentional; in her discussion of the decorative program of portraits of Greeks at the Villa of Cassius at Tivoli, Dillon writes, '[one can] imagine the wide range of possible

79 Brown (n. 73), 63.

80 In a villa at Welschsbillig is a series of late fourth-century herms depicting classical thinkers, orators, and generals: see Smith (n. 42), 151f. For German mosaics, see K. Parlasca, Die Römische Mosaiken in Deutschland (Berlin, 1959). The late third- to early fourth-century 'Monnus', now in the Landesmuseum in Trier, includes bust-length portraits identified by inscriptions as Virgil, Menander, Ennius, Hesiod, the Muses, and personifications of the Seasons and the Months: op. cit., 41ff. A mosaic from the 'Procuratoren Palast' has an unidentified standing togate figure, and a fragment that depicts a seated portrait of Anaximander: op. cit., 28f. In the Römisch-Germanisches Museum in Cologne, the 'Philosophenmosaik', dated between the late-second and mid-fourth century, includes seven hexagons with bust-length images of philosophers. The surviving figures are inscribed as Diogenes, Cheilon, Kleoboulos, Socrates, and Sophocles: op. cit., 80-2, pls. 80-2.

$81 \operatorname{Kempf}($ n. 1), 158.

82 Simon (n. 6), $20 \mathrm{ff}$.

83 Weber (n. 2), 22.

84 Brandenburg (n. 6), $188 \mathrm{f}$.

85 The Cologne mosaic serves as an example of the confusing effect Late Antiquity's fluid philosopher types have had on scholars' interpretations. Parlasca (n. 80), 82, thought that the inscriptions for Sophocles and Socrates had been switched by mistake, but actually none of the philosopher images follow their traditional portrait characteristics; the Silenus of Socrates is diminished in the Cologne mosaic. 
associations, quotes, and obscure stories these portraits could have evoked. ${ }^{86}$ The majority of philosophers on the pavements and on the ceiling, however, do conform to the general late Roman descriptions of the ideal philosopher: old, with long hair and beard, handsome face, with a focused or calm expression. ${ }^{87}$ As with the female images, I believe that these were meant generally to recall a type, in this case evoking paideia and Romanitas, in order to impress guests and promote conversation.

The decorative program of the ceiling painting, with references to material wealth, familial harmony, and education, in such a large room, suggests that the domestic complex belonged to a family from the upper echelon of Trier's society, whether Constantine's family or otherwise. Kempf called the room an imperial 'Prunksaal', or grand reception space. ${ }^{88}$ Although there is a lack of evidence for the relationship of the painted room to other spaces in the house, the room's size indicates that it was used for receiving and entertaining visitors. ${ }^{89}$ Rooms that have been identified as audience chambers in Late Antique aristocratic homes, however, usually have apses, and are preceded by vestibules into which visitors or clients would enter from the street. ${ }^{90}$ Richly designed reception rooms were markers of Romanitas in the provincial élite architecture. ${ }^{91}$ The lack of an apse in the room in Trier does not preclude its use as an audience chamber. Spaces in the late empire were fluid, and often were used for multiple purposes such as official receptions and social entertaining. The ceiling's references to domestic harmony lead to the conclusion that the room was for social functions and personal guests as well as for clients. Entertainment in this period meant banquets, and rooms used for dining were carefully decorated in order to impress guests. ${ }^{92}$ The Trier room, whether serving as an official or social space, would accommodate many guests and servants. ${ }^{93}$

${ }^{86}$ Dillon (n. 77), 40.

87 Smith (n. 42), 146.

${ }^{88}$ Kempf, 'Der vorläufigen Ergebnisse der Ausgraben auf dem Gelände des Trierer Domes', Germania 29 (1951), 47ff.

89 See further S. Ellis, Roman Housing (London, 2000), 172, for large reception rooms and dining rooms in Late Antiquity.

90 According to Ellis (n. 21), private audience chambers can be identified in aristocratic houses in Apollonia, Ephesus, and Aphrodisias.

91 Ellis (n. 89), $59 \mathrm{ff}$.

${ }_{92}$ Dunbabin (n. 22), 66-80. Many, but not all, triclinia in Late Antiquity were apsed to accommodate curved couches: id., 'Triclinium and Stibadium', in W. J. Slater (ed.), Dining in a Classical Context (Ann Arbor, 1991), $121 \mathrm{ff}$.

93 The orientation of the figures on the ceiling is such that people throughout the room would have seen at least one row of figures right-side up. If used as a dining room, the privileged 
The ceiling therefore would have been seen by more than the house's owners. Guests would have been struck by the evidence of domestic and material prosperity that the ceiling illustrates. They would have been impressed at the display of the host's status and Romanitas, honoured to be in such a space and reaffirm that special connection with their host through paideia. The decor served to promote a certain Roman order in the provinces, particularly in Trier, which had a varied population of natives and people from the eastern and western areas of the Roman Empire. ${ }^{94}$

\section{Conclusion}

A broad theme therefore is evident in the painted ceiling of the chamber discovered under Trier Cathedral. Instead of specific gods and goddesses, personifications, philosophers, or portraits of the owners, the artist has chosen various elements from all of these figures to create an atmosphere of affluence, culture, and magical domestic harmony. The ceiling's ambiguous references to mythology, literature, and philosophy would have served as the subject of learned conversation within the room. The ceiling's women, the philosopher portraits, and putti bearing objects of silver and gold, asserted the place of the patron and his family in society, as well as constructing their identity as privileged and cultured Romans.

person would be the one on the couch in the middle of the room facing east, who would have seen the central figure facing his or her way. There is a room of a similar scale in the Villa Arianna at Stabiae, $6.4 \times 10.2 \mathrm{~m}$.; Dunbabin (n. 22), 70. However there is no known view of the outside in Trier, which was an important aspect of many Late Antique dining rooms.

94 Wightman (n. 26), 62f. 
Reproduced with permission of the copyright owner. Further reproduction prohibited without permission. 